\title{
USING SHORT STORY TO IMPROVE STUDENT'S READING COMPREHENSION (A STUDY AT THE SECOND YEAR STUDENT OF SMPN 2 KOTA BENGKULU)
}

\author{
Amelia Eka Frimasary \\ Syahrial \\ University of Bengkulu \\ Bengkulu, Indonesia 38371 \\ E-mail: Amelia86khasanan@gmail.com \\ E-mail: Eric.syahrial@gmail.com
}

\begin{abstract}
The objective of this research was to know the differences in students score and also to know whether the student's interest was improved or not, after did a treatment using short story and handbook. The instrument of this research was questionnaire. The result from short story was satisfactory. The mean score from pre-test was 45.1 for experimental class and 45.25 for control class. The difference both of class was 0.15 point. The result of post-test was 55.9 for the experimental class, and 51.8 for the control class. The difference in both classes was 4.1. It can be concluded that the experiment was success. The explanation above showed that the differences in improving students' score and interest by giving the treatment, and the differences score between two classes are significant. It means that reading activity by using short story could improve students reading comprehension in class I of SMPN 2 Kota Bengkulu.
\end{abstract}

\section{Keywords: Short Story, Reading}

Abstrak: Jurnal ini ditulis untuk mengetahui perbedaan nilai dan peningkatan nilai siswa setelah menggunakan perbandingan tekhnik antara penggunaan short story dengan penggunaan material handsbook (buku paket) sekolah. Selain itu Instrument penelitian ini adalah questionnaire. Hasil yang di dapat ternyata memuaskan. Untuk mengetahui hasil dari eksperimen ini, peneliti melakukan pre-test. Hasil nilai rata-rata pre-test adalah 45.1 untuk kelas experiment dan 45.25 untuk kelas kontrol. Perbedaan selisih nilai untuk kedua kelas adalah 0.15 point. Sementara itu hasil post-test adalah 55.9 untuk kelas eksperimen dan 51.8 untuk kelas kontrol. Perbedaan nilai kedua kelas mencapai 4.1 point. Jadi bisa dikatakan experiment berhasil. Dari penjelasan di atas bisa diketahui perbedaan antara nilai siswa dan ketertarikannya setelah diberikan cerpen, dan perbedaan nilai siswa yang diberikan handbook adalah signifikan. Ini berarti bahwa aktivitas membaca dengan menggunakan cerpen bisa meningkatkan pemahaman siswa dalam membaca di kelas I SMPN 2 Kota Bengkulu.

\section{Kata Kunci : Cerita Pendek, Membaca}

\section{INTRODUCTION}

English is a purely foreign language in Indonesia. Therefore, Indonesian students especially Junior High School, find difficulties in learning English. There is no way for them except trying to learn English if they want to adapt themselves in these era. The success of someone in learning is often supported by his willingness to read a lot. It does not matter whether he reads scientific writing (journal or books on social or natural sciences) or popular writing (magazines, newspaper, or novels). 
All of that give a lot of advantages to the reader to increase his knowledge. The student's interest in reading is very important for improving their achievement, because if the students do not have interest in it they will not be eager to read.

Reading is a multifaceted process involving word recognition, comprehension, fluency, and motivation, Leipzig (2001). It learns how readers integrate these facets to make meaning from the printed materials. Emerald (1932) in Ramlan (2002) says that reading is more than a symbol recognition of graphic symbols of words. Its progressive comprehension of the meaning and ideas are represented by a sequence of words. It includes seeing the word, recognizing the word to its context. From the description we could say the reading is not simply thing, calling out the name of the words, but complex intellectual process, knowing the meaning of the words and massage of the text.

Basically, reading is an advantageous activity, although the motivation of people to read is varied. People read to get information, to learn something, or just for fun. We often hear an opinion which says that the more we read, the more knowledge we learn. Reading can be entertaining as well as informative. It is not an exaggerated statement, for we really take a lot of advantages through reading, no matter what we read (whether we read scientific books or articles or popular ones). By reading we will know and get something to enrich and enlarge our knowledge. People who like reading have the biggest opportunity to improve their career. In today's school, the importance of reading has been emphasized to the students.

Most of us think of reading as a simple, passive process that involves reading words in a linear fashion and internalizing their meaning one at a time. But reading is actually a very complex process that requires a great deal of active participation on the part of the reader.

As we can see, reading involves many complex skills that have to come together. For example, proficient readers recognize the purpose for reading, approach the reading with that purpose in mind, use strategies that have proven successful to them in the past when reading similar texts for similar purposes, monitor their comprehension of the text in light of the purpose for reading, and if needed adjust their strategy use. Proficient readers know when unknown words will interfere with achieving their purpose for reading, and when they won't. When unknown words arise and their meaning is needed for comprehension, proficient readers have a number of word attack strategies available to them that will allow them to decipher the meaning of the words to the extent that they are needed to achieve the purpose for reading. Reading is also a complex process in that proficient readers give to the text as much as they take. They make meaning from the text by using their own prior knowledge and experiences. Proficient readers are constantly making predictions while reading. They are continuously anticipating what will come next. Their prior knowledge and 
experiences with texts as well as with the world around them allow them to do this. It is this continuous interaction with the text that allows readers to make sense of what they are reading

Bums, et all, (1984) say "teachers must show children that being able to read is rewarding in many ways that it increases success in school, bestows status, and provides recreation. Then, Mason and $\mathrm{Au}$ (1990) give a concept that reading is a social process and becomes one of the means people count on to accomplish everyday goals and to make sense of their lives. Here, social process means that reading is one Of the means people employ to communicate with each other and to work toward

The unwillingness in reading and the need to achieve a success in English among junior high school students create a problem. They want to improve their English, but they are not really willing to read English. They consider that English is difficult to learn before eventually trying to learn it.

The Researcher has done a presurvey in the place that will be used as target of population in this research. In SMPN2 Kota Bengkulu especially in class VIII, they always

\section{METHODS}

This study was a quasiexperiment that there are two classes that will be observed, they are class $I$ and $J$ and using two materials that must be taught in the class. Class I as experimental used the material of literary work while the class $\mathbf{J}$ used the book as control class. In this read English materials lazily in the classroom. They said the materials or the topics are not interested to read. They bored of the monotonous topic. That makes one reason for a researcher to introduce a new way to encourage the reading willingness in student itself using short story. The researcher using short story because in teenagers' level, short story is the most interested literary work to read. It becauses short story is not too long to read and has various interesting topics. So hopefully through this way, they can improve their comprehension in reading without boredom.

The researcher chose SMPN2 Kota Bengkulu to be a population and sample because as we know that SMPN2 is one of the favorites school in Kota Bengkulu beside SMPNI and SMPN4. The researcher chose this school because the researcher saw the real trouble like researcher explained above. In this case, it is probably useful for the students to improve their comprehension in reading.

Based on those explanations, the objective of this study is to know whether short story can improve the students' reading comprehension or not.

experiment, the materials were taught in the two classes. Each group was treated by using diffirent technique whether in short story and handbook. This design was done in eight meetings. The design of both materials waas showed in the following table: 
Table. 1. Design

\begin{tabular}{|c|c|c|c|}
\hline Group & Pre-test & $\begin{array}{c}\text { Independent } \\
\text { Variable }\end{array}$ & Post-test \\
\hline $\mathbf{E}$ & $\mathbf{Y}$ & $\mathbf{X}$ & $\mathbf{Y}$ \\
\hline $\mathbf{C}$ & $\mathbf{Y}$ & - & $\mathbf{Y}$ \\
\hline
\end{tabular}

Furthermore, the sources of data or the population were the students of Junior High School number 2 (SMP N 2) Bengkulu city at the second year. In this research, researcher took two classes for sample and consisting of about 80 students. They were class I and $\mathrm{J}^{\prime}$ Actually, the total class of second years students of SMP Negeri 2 Kota Bengkulu are ten, they are class A to J. But researcher just took two classes that had a same characteristic. Karto (in Ramlan , 2002) convey that principally, there is no fixed rule to determine how many samples or percentages $(\%)$ of its sample that must be taken from the population.

The researcher analyzed the data by using the test and questionnaire.

\section{RESULTS AND DISCUSSION}

The data for this research was gotten from test and questionnaire. The researcher sets up the questionnaire to investigate the student's motivation in reading English. In this instrument, the opinion and the factual information are obtained. The questionnaires are in the form of statements in which the respondents are to cross the option they think most appropriate for them. The type of questionnaire that will use in this research is a close questionnaire. Its mean that all items have four
The researcher sets up the questionnaire to investigate the student's motivation in reading English. In this instrument, the opinion and the factual information were obtained. The questionnaires are in the form of statements in which the respondents are to cross the option they thought most appropriate for them. The type of questionnaire used in this research was a close questionnaire. It means that all items had four choices. Then each choice was measured by using t-test. Besides, researcher will use short story and some exercise from the short story to measure the reading comprehension of the students

choices, then each choice measured by using t-test. Beside that researcher will use short story and some exercise from the short story to measure the reading comprehension of the students. Before conducting the research, the researcher gave pretest to gain the baseline data. The pretest was used to support the empirical data and to get basic score of students speaking before applying the strategy. The students score showed in following table:

Table 2. Pretest Score

\begin{tabular}{|c|c|c|l|}
\hline No & $\begin{array}{c}\text { Total } \\
\text { Subject }\end{array}$ & $\begin{array}{l}\text { Total Score in } \\
\text { Control Class }\end{array}$ & $\begin{array}{l}\text { Total Score in } \\
\text { Experiment Class }\end{array}$ \\
\hline
\end{tabular}




\begin{tabular}{|c|c|c|c|}
\hline 1 & 40 & 1810 & 1804 \\
\hline & MEAN & 45.25 & 45.1 \\
\hline
\end{tabular}

The result showed that the total score in control class was 1810 , and the mean score was 45.25. Furthermore in the experimental class, the total score was 1804 and the mean was 45.1. The differences of mark between both of classes were not too dominant' There was no one students that got the highest score (100), while in the control class there was one student. The highest just get 56 and the lowest get 36.And that's mean that there is no significant differences both of them. Thus it could be concluded that the students' ability for this class was good enough.

Furthermore, after doing the treatment for eight meetings to the experimental class and control class using short story and handbook materials, then the researcher did the post test for both classes to know that there were differences between pretest and post-test. The score of the post-test in the following table:

Table 3. Post-Test Score

\begin{tabular}{|c|c|c|c|}
\hline No & Total Subject & $\begin{array}{l}\text { Total Score in } \\
\text { Control Class }\end{array}$ & $\begin{array}{l}\text { Total Score in } \\
\text { Experiment Class }\end{array}$ \\
\hline 1 & 40 & 2072 & 2236 \\
\hline & MEAN & 51.8 & 55.9 \\
\hline
\end{tabular}

The result score of the experimental class was very different from control class. It showed that the total score in experimental class was 2236, while in the control class was 2072. The mean score in experimental class was 55.9 while in control class was 51.8. As compared class increases 164 point As compared the high score the short story with handbook there were some students who got the highest score while in the control class no one student who got that score. It could be concluded that there was differences between the result of experimental class

From the result of pretest calculation, $\mathrm{t}$ obtained was 0.11 , at degree of freedom was $(40-1)+(40-$
1) $=78$, and p level was determined 05 . Therefore, there was not df 78 in the $\mathrm{t}$ table, that the writer used $78 \mathrm{df}$. The t table value at $05 \mathrm{p}$ level and 78 df in two tailed is 1,68 . Thus, the $t$ obtained was smaller than $t$ table $(0.24<1.68)$. It concluded there was no significant difference between the mean score of both groups. It means both groups could be accepted as the sample in the study.

From the result of test calculation, the $t$ obtained was 2.54 while in the $t$ table value of $78 \mathrm{df}$ and at $05 \mathrm{p}$ level 1.68. so, the $t$ obtained was bigger than $\mathrm{t}$ table $(2.54>1.68)$. The researcher concluded that there is a significant difference between the mean score of experimental group and control group consequently, the 
alternative hypothesis (H1) was accepted and the null hypothesis (H6) was rejected. In conclusion the hypothesis .There was differences in students score and improvement between the two classes of experimental class and control class in reading activity' was statistically acceptable or the research hypothesis was accepted.

After the treatment, all the students of experimental group were asked to fill the questionnaire. The purpose was to know whether they were interested in learning reading English through short story or not. The total number of the students that filled the questionnaire was 40 students.

The result of the questionnaire shows that 28 students (7yo/o)said that they liked learning English and 12 students $(30 \%)$ of them did not like learning English. 23 students $(57.5 \%)$ said that they prefer to read short story, 5 students (12.5\%;) prefer prose, and 12 students $(30 \%)$ prefer poetry. 36 students $(90 \mathrm{o} / \mathrm{o})$ said that they liked short story and 4

\section{CONCLUSION}

Based on the research done in SMPN 2 Kota Bengkulu, it was found that short story can improve reading comprehension of the students. Short story made students interest and have willingness to eager to read the text of English. In addition, after researcher used this way for the students. the result was successful to increase the score of the students. Based on the conclusion, the researcher would like to give some suggestions as follows:

1. The teacher should teach reading class by using short students (10\%) did not like short story. 15 students $(37.5 \%)$ said that they always found difficulties in learning grammar in each of theme in their text book. 24 students $(60 \%)$ seldom got difficulties and I students (25\%) never found any difficulty in learning grammar.32 students $(80 \%)$ said that their teacher seldom give the sentence pattern, 25 students $(62.5 \%)$ sometimes had difficulties in creating a sentence, and five students $(12.5 \%)$ said that they did not have any difficulty in making a sentence.

Asking about their opinions about studying English grammar by using short story, it was found that 36 students $(90 \%)$ said that the story or text that is written in English helped them in learning English grammar and four students said that the story did not give any contribution in learning grammar. Thirty three students $(52.5 \%)$ prefer to study English grammar by using short story, and $\mathrm{T}$ students did not like to study grammar by using short story.

story by using simple English and stay away from using monotonous text or handbook. Because not all of the students take a course and also they have different ability and background.

2. The class can use reading materials provided by the teacher to make the students enjoyable in reading class. Short story can make them fresh and knowledgable about variation of reading and its content 


\section{REFERENCES}

Burns, Paul. C., Roe, Betty. D. and Ross, Elinor. P.1984. Teaching Reading in Today's Elmentary Schools. Boston : Houghton Mifflin Comapany.

Leipzig, D.H. 2001. What is Reading. WWW.Google.co.id. 17 November 2007. 03pm.

Mason, Jana. M. and Au, Kathryn. H. 1990. Reading Instruction for Today. USA: Harper Collins Publishers.

Ramlan. 2002. Improving Students Reading Motivation by Using Anecdote. Unpublished Thesis. Bengkulu: Universitas Bengkulu 




